\title{
PELATIHAN PEMBUATAN TEPUNG MOCAF SEBAGAI PENGGANTI TEPUNG TERIGU DI KELOMPOK WANITA TANI ENGGAL MUKTI
}

\author{
Riswanto*, Anak Agung Oka, Siti Suptihatin, Teguh Santoso, \\ Lia Wijaya, Nur Indah Sari \\ Fakultas Pendidikan MIPA, Universitas Muhammadiyah Metro \\ email: rumbiariswan@gmail.com
}

\begin{abstract}
Community service in Reno Basuki village, Rumbia, Central Lampung was focus to develop the group of farm women or KWT. KWT is one of the way to make a good effect on economics situation of society and also the way to solve the problems of national economics. The biggest comodity in KWT Enggal Mukti is cassava. Product from cassava can be a solution of Indonesian's problem. One of the problem about economics in Indonesia is about the number of using wheat flour. As we know that wheat flour was produced by using wheat and Indonesia cannot produce it. So, the Indonesian's goverments have a decision to import it from the other country. This situation is not good for Indonesia because it can make bad impact for Indonesia. The way to solve this condition is looking for the other kind of flour, and one of them is MOCAF (Modified Cassava Flour). Finally, the community service in KWT Enggal Mukti is training about 'how to make mocaf'.
\end{abstract}

Keywords: KWT, Training, Mocaf

\begin{abstract}
Abstrak
Pengabdian kepada masyarakat yang dilaksanakan di kampung Reno Basuki, Rumbia, Lampung Tengah terfokus pada pengembangan kelompok wanita tani (KWT). KWT sebagai salah satu tonggak perubahan perekonomian keluarga menjadi sebuah jalan untuk memperbaiki perekonomian nasional. Komoditas yang melimpah di kawasan KWT Enggal Mukti adalah singkong. Pemanfaatan singkong menjadi sebuah jalan baru untuk menyelesaikan permasalahan perekonomian di Indonesia Permasalahan yang kini terjadi adalah adanya kecenderungan masyarakat Indonesia dalam menggunakan tepung gandum, baik dibuat dalam bentuk olahan gorengan, kue, atau yang lainnya. Akan tetapi, gandum bukanlah komoditas asli dari Indonesia sehingga pemenuhan gandum dilakukan dengan cara impor. Hal ini pastilah sangat berdampak pada perekonomian nasional. Oleh karena itu, pada pengabdian masyaraakt ini akan dilakukan pelatihan pembuatan mocaf (modified cassava flour) sebagai alternatif pengganti tepung terigu.
\end{abstract}

Kata Kunci: KWT, Pelatihan, Mocaf

\section{PENDAHULUAN}

Kelompok Wanita atau KWT adalah wadah bagi ibu-ibu (wanita) untuk berkarya dan meningkat peluang untuk meningkatkan kesejahteraan keluarga. Peningkatan produktivitas tenaga kerja wanita tani memiliki peran dan potensi yang strategis dalam mendukung peningkatan maupun perolehan pendapatan rumah tangga pertanian di
pedesaan.(Ervinawati, Fatmawati, \& L, 2015)

KWT Enggal Mukti merupakan salah satu KWT yang berada di kampung Reno Basuki, kecamatan Rumbia, kabupaten Lampung Tengah. Produksi utama dari KWT Enggal Mukti adalah tiwul. Hal ini didasari oleh komoditas utama yang ada di lingkungan KWT, yaitu singkong. Seiring berjalannya waktu, KWT Enggal Mukti 
perlu melebarkan sayapnya dalam melakukan produksi dengan bahan dasar singkong.

Singkong atau ketela pohon atau ubi kayu Singkong, yang memiliki nama latin manihot escelanta merupakan tanaman umbi-umbian yang dapat tumbuh subur di sebagian besar wilayah di Indonesia. Singkong sering hanya dianggap sebagai umbi yang dapat diolah sebagai tepung tapioka dan berbagai macam makanan. Salah satu yang dapat diproduksi dengan menggunakan singkong adalah Mocaf atau Modified Cassava Flour.

Pembuatan tepung dari casava kering selain merupakan usaha pengawetan juga sekaligus membuat lebih ringkas dan lebih luwes untuk dimanfaatkan sebagai bahan dasar maupun bahan subtitusi beragam olahan makanan.(Haryadi, 2011)

Mocaf merupakan sebuah solusi untuk menurunkan angka konsumsi tepung terigu.Tepung terigu merupakan hasil olahan dari biji gandum yang bukan hasil alam Indonesia. Penggunaan tepung terigu yang tinggi membuat pemerintah memilih solusi dengan melakukan impor gandum dari luar negeri. Ketergantungan impor merupakan permasalahan yang berulang setiap tahunnya, masalah ini dikarenakan konsumsi tepung dalam negeri yang meningkat serta bahan utama dari tepung yaitu biji gandum bukanlah jenis tanaman yang berasal dari Indonesia.(Separinta, 2017)

Indonesia merupakan negara importir gandum terbesar keempat di dunia. Kebutuhan gandum domestik setiap tahun menignkat disebabkan oleh semakin berkembangnya makanan berbasis tepung terigu. Menurut data FAO, perkembangan impor gandum Indonesia dari tahun 19922011 setiap tahunnya rata-rata meningkat sekitar 6,4\%. Berdasarkan kondisi perekonomian saat ini dan nilai tukar rupiah yang rendah, tentu sangat memberatkan ketika melakukan impor.(Pradeksa, Darwanto, \& Masyhuri, 2014)

Besarnya kebutuhan gandum dalam negeri sebanding dengan meningkatnya permintaan tepung terigu. Peningkatan konsumsi tepung terigu Indonesia tercatat dari $9 \mathrm{~kg} / \mathrm{kapita}$ pada tahun 1990 menjadi 19,72 kg/kapita pada akhir 2012. Permintaan tepung terigu tertinggi berasal dari industri mie instan, kemudian diikuti biskuit, bakery, dan rumah tangga.(Yanuarti \& Afsari, 2016)

Tepung Mocaf menjadi produk alternatif yang dapat dikembangkan oleh KWT Enggal Mukti. Fungsi dan kegunaan tepung mocaf serta melimpahnya bahan baku pembuatan mocaf menjadi alasan terkuat untuk melanjutkan program pembuatan tepung mocaf sebagai salah satu produk hasil kerja KWT Enggal Mukti.

\section{METODE PENGABDIAN}

Pelaksanaan program pengabdian berupa pelatihan pembuatan tepung Mocaf ini dilaksanakan dengan menggunakan metode ceramah, diskusi, dan pendampingan. Ketiga metode ini dilakukan dengan berkelanjutan serta berkesinambungan.

Ceramah diisi dengan pemaparan materi oleh pemateri tentang proses pembuatan tepung mocaf. Metode ceramah dipilih sebagai sarana untuk memperkenalkan serta memberikan pengetahuan kepada peserta tentang proses pembuatan mocaf. Proses pembuatan tepung mocaf memiliki kemiripan di awal dengan proses pembuatan tiwul sehingga peserta (ibu-ibu) anggota KWT mudah untuk memahami materi yang disampaikan.

Diskusi diisi dengan pengajuan pertanyaan dari peserta kepada pemateri. Hal ini dilakukan sebagai bentuk konfirmasi dari materi yang telah disampaikan oleh pemateri. Ketidakjelasan ataupun kerumitan dapat langsung diurai dengan metode ini. Selain itu, semakin banyak pertanyaan yang muncul dari peserta dapat dijadikan suatu sumber ilmu bagi peserta lainnya.

Pelaksanaan program pengabdian masyarakat yang telah dilakukan meliputi 4 tahap, yaitu

1. Tahap Analisis Kondisi 
Tahap analisis kondisi dilakukan sebagai bentuk pemetaan kebutuhan. Hal ini penting untuk dilakukan dengan tujuan meminimalisir adanya program yang kurang sesuai dengan kondisi nyata. Tahap ini dilakukan dengan mengumpulkan informasi, baik berupa hasil wawancara ataupun dari dokumen-dokumen resmi dari KWT Enggal Mukti.

Informasi yang diperoleh kemudian dianalisis dan disimpulkan sehingga diperoleh sebuah titik temu, yaitu diperlukannya pelatihan pembuatan tepung Casava untuk anggota KWT Enggal Mukti.

2. Tahap Persiapan

Tahap persiapan diawali dengan menyusun konsep acara sesuai dengan hasil analisis kondisi KWT. Selanjutnya, berkoordinasi dengan pemateri yang sesuai dengan kebutuhan. Selain itu, tahap persiapan juga berisi tentang persiapan teknis dari kegiatan pelatihan meliputi waktu dan tempat, term of reference (TOR) atau garis-garis besar materi yagn harus disampaikan oleh pemateri, sarana dan prasarana yang dibutuhkan, serta konsep teknis acara.

3. Tahap Pelaksanaan

Tahap pelaksanaan kegiatan meliputi:

a. Pemaparan Materi

Peserta pelatihan akan mendengarkan materi yang disampaikan oleh pemateri. Materi yang disampaikan tidak hanya terkait tentang proses pembuatan tepung mocaf, melainkan juga berisi tentang motivasi untuk selalu bergerak dan berinovasi, serta membuka cakrawala peserta tentang sebuah usaha dan hasil. Mental peserta pelatihan perlu dibangun untuk memberikan sebuah keyakinan dan kepercayaan diri bahwa setiap yang diupayakan pasti akan membuahkan hasil meski waktu berbuahnya tidak selalu cepat. b. Diskusi

Diskusi dilakukan setelah pemaparan materi tentang proses pembuatan tepung Mocaf selesai. Diskusi dilakukan sebagai bentuk konfirmasi dari peserta pelatihan kepada pemateri ataupun sebaliknya, sehingga tidak terjadi kekeliruan.

4. Tahap Tindak Lanjut

Tahap tindak lanjut adalah tahapan diluar acara pelatihan. Akan tetapi, tahapan ini sangat berpengaruh terhadap sukses atau tidaknya pelatihan. Tahap tindak lanjut yang dimaksudkan adalah mendampingi KWT Enggal Mukti pasca dilaksanakannya pelatihan

\section{HASIL DAN PEMBAHASAN}

Kegiatan pelatihan pembuatan tepung mocaf dilaksanakan dalam 4 tahap. Akan tetapi, secara teknis, kegiatan pelatihan (penyampaian materi) hanya berfokus pada tahap pelaksanaan.

Kegiatan pelatihan pembuatan tepung Mocaf dilaksanakan di balai desa Restu Baru pada hari Kamis, 01 Agustus 2019. Pemateri dalam pelatihan ini adalah ibu Suparti selaku ketua Asosiasi Kelompok Wanita Tani, yang telah lama malang melintang dalam dunia KWT.

Ibu Suparti, dengan segundang pengalamannya dalam membangun KWT tidak hanya berfokus pada materi tentang pembuatan tepung mocaf. Akan tetapi, beliau juga menekankan pada indahnya sebuah proses untuk menjadi lebih baik (dalam konteks pengembangan KWT). Hal ini beliau lakukan untuk membangun support system di tubuh KWT Enggal Mukti, sehingga jika suatu saat mengalami masa kritis maka akan tetap ada suatu sistem yang berjalan sehingga tidak larut dalam masalah tanpa mengupayakan penyelesaiannya.

Ibu Suparti, sesuai dengan judul pelatihannya yaitu "Pelatihan Pembuatan Tepung Mocaf" maka beliau memaparkan 
proses pembuatan tepung Mocaf yang meliputi

1. Pemilihan singkong

Singkong yang diutamakan dalam pembuatan tepung Mocaf adalah singkong yang tidak beracun.

2. Pengupasan singkong

Singkong dikupas sampai bersih (tidak menyisakan kulitnya) untuk menjaga kesehatan produk tepung Mocaf.

3. Pemotongan singkong

Singkong dipotong kecil dan tipis agar singkong dapat terfermentasi dengan baik. Kemudian singkong dicuci bersih dan dimasukkan ke dalam bak besar atau secukupnya bahan singkong yang ada.

4. Fermentasi singkong

Fermentasi singkong menggunakan larutan garam. Singkong yang sudah dicuci bersih kemudian direndam dalam air garam selama 2 malam.

5. Pencucian dan penjemuran singkong Pencucian singkong dilakukan untuk menghilangkan sisa-sisa proses fermentasi, sehingga diperoleh singkong yang tetap bersih. Setelah singkong dicuci bersih maka selanjutnya dijemur hingga kering.

6. Penggilingan

Singkong yang telah difermentasi dan dijemur hingga kering kemudian digiling sampai halus (menjadi tepung).

7. Tahap akhir

Tahap akhir dalam pembuatan tepung Mocaf adalah pengayakan hasil gilingan singkong dan pengemasan.

\section{SIMPULAN}

Berdasarkan hasil dan pembahasan tentang program pengabdian masyarakat dalam kegiatan pelatihan pembuatan tepung Mocaf, simpulan dari kegiatan tersebut adalah sebagai berikut:

1. Kegiatan pelatihan ini berujuan untuk melebarkan cakrawala anggota KWT Enggal Mukti terkait produk hasil olahan singkong.
2. Variasi produk hasil olahan singkong dapat menjadi sebuah solusi dalam mengurangi angka ketergantungan terhadap tepung gandum atau tepung terigu.

\section{UCAPAN TERIMA KASIH}

Kami mengucapkan terima kasih kepada :

1. Lembaga Pengabdian Kepada Masyarakat Universitas

Muhammadiyah Metro sebagai lembaga yang memberikan kesempatan dilakukannya program pengabdian.

2. Kelompok Wanita Tani Enggal Mukti sebagai tempat penyelenggaraan program pengabdian.

3. Perangkat desa Reno Basuki, kecamatan Rumbia, Lampung Tengah yang telah memberikan izin dan dukungan selama pelaksanaan program pengabdian.

\section{DAFTAR PUSTAKA}

[1]. Ervinawati, V., Fatmawati, \& L, E. I. (2015). Peranan kelompok wanita tani perdesaan dalam menunjang pendapatan keluarga. Jurnal Tesis, 117.

[2]. Haryadi. (2011). Teknologi modifikasi tepung kasava. 31(2), 8692.

[3]. Pradeksa, Y., Darwanto, D. H., \& Masyhuri. (2014). Faktor-Faktor yang Mempengaruhi Impor Gandum Indonesia. Agro Ekonomi, 24(1), 4453.

[4]. Separinta, A. (2017). Kepentingan Pemerintah Indonesia Mengeluarkan Kebijakan Pembatasan Kuota Impor Tepung Gandum. Jurnal Online Mahasiswa, 4(2), 1-7.

[5]. Yanuarti, A. R., \& Afsari, M. D. (2016). Komoditas Terigu (O. Nurwan, ed.). Jakarta: Dirjen Perdagangan Dalam Negeri. 